\title{
The Relationship between Lending Rate and Nonperforming Loans in Commercial Banks: Evidence from Pakistan (2008-2014)
}

\author{
IHTESHAM KHAN \\ Assistant Professor, Abdul Wali Kahn University, Mardan \\ ihtishamkhan@awkum.edu.pk \\ ROOHUL AMIN \\ MBA-student, Abdul Wali Kahn University, Mardan \\ SHAH RAZA KHAN \\ Iqra National University, Peshawar \\ MUHAMMAD ILYAS \\ Lecturer, Abdul Wali Kahn University, Mardan \\ Milyas85@awkum.edu.pk
}

\begin{abstract}
The objective of the study was to examine the relationship between lending rate and nonperforming loans in commercial banks of Pakistan. The study collects data on bank size and nonperforming loans from the annual reports of commercial banks and lending rates data was collected from the state bank of Pakistan statistical bulletins for the period of 2008-2014 and the data was analyzed through SPSS to examine the relationship between lending rate and nonperforming loans. The study used correlation and regression methods. The study found a significant positive relationship between lending rate and nonperforming loans in commercial banks of Pakistan.
\end{abstract}

Keywords: Lending Rate, Nonperforming Loans, Commercial Bank.

\section{Introduction}

Commercial banks perform a vital role in the economic development of the country in providing a medium of exchange. They promote the distribution of credit to the productive sector of the economy. These institutions play an important role in developed and underdeveloped countries. Commercial banks not only facilitate the flow of credit but also increase productivity by providing loans to the various sectors of the economy (Asantey \& Tengey, 2014). Like every country of the world the banking sector of Pakistan play major role in the economic development of Pakistan. Badar and Yasmin (2013) stated that the main function of the banks is the creation of credit through mobilization of deposits. The banks give low interest on deposits from customers and charge high interest rate on lending to customers. This interest spreads are the profit for 
banks. Similar to other business the prime objective of commercial banks is to maximize their profit. The main source of income of banks is the interest income which they earn on their lending to customers. According to De Buck and Demyanets (2012) that lending interest rate is the fee or amount which bank charge when they lend money to the borrowers. They further, stated that these rates are set in accordance with the cost sustained by bank and the profit which bank will earned on lending loans to its customers. The bank lending decision has more importance, because the future profitability and performance are determine by it. Banks are recently becoming very conscious in selection of customer to refrain the bad effect of nonperforming loans (Lata, 2015). Nonperforming loans (NPLs) are harmful for the asset quality of banks which effect the wealth and financial soundness of banks Therefore, the bank will be very conscious during lending to borrowers because if huge amount of loan default it will adversely affect liquidity and asset quality of the bank (Hassan, Ilyas \& Rehman 2014).

The performance of commercial banks hanged to the rate at which they lend their monies to borrowers. While on the opposite the repayment of these funds are stressed by the lending rates which deduce their disposable income (Walsh, 2010). Therefore, the efficient and effective management of lending rates have positive affect on the performance of banks as well as on the whole country. So it is needed to make strong policies to control and monitor the bank lending rates to promote the soundness of financial sector. Commercial banks' lending rate is determined by the central bank rate or base rate. According to Kidwell (2008) base rate are monitor by the central bank of the country to assist the monitory policy. So the overnight reserve of central bank consists of lending and borrowing among commercial banks. Therefore the central bank rate is very important to maintain reserves available in banks, which also affect the commercial bank lending decision to customers. Justin (2013) stated that credit risk is borrower's inability to repay his loan obligations on agreed time. These arise because of borrowers income unchanged regardless of sudden change in banks' lending rate.

Masood (2009) argued that the most critical issue face by the Pakistani banking sector is a lot amount of non-performing loans which not only affect the banking industry but also affect the economic condition of Pakistan. In Pakistan more loan are given on political basis, that's why more loan become default. Further political interference should be removed from banking affairs through proper legislation (Awan, Nadeem \& Anjum 2015). According to the World Bank Pakistan is on $14^{\text {th }}$ position in the list of nonperforming loans country. The average value Pakistan nonperforming loans were $14.4 \%$ from 2000 to2013, from which $23.4 \%$ is the maximum in 2001 and $7.3 \%$ was the minimum in 2006. According to state bank of Pakistan (2013) the total amount of nonperforming loans is RS 585 billion for all banks in Pakistan. Out of these total nonperforming loans $69 \%$ came from the balance sheet of private banks and $27 \%$ reside on the balance sheet of public sector commercial banks, $6 \%$ came from specialize banks and approximately $1 \%$ from foreign banks.

\subsection{Problem Statement}

The problem statement is to find the relationship between interest rate offered by banks and non performing loan. 


\subsection{Research Question}

- What is the relationship between lending rate and nonperforming loans in Pakistani commercial banks?

\section{Literature Review}

The theory elucidates that how lending rate is fixed by the commercial banks in the market. These theories are of great importance to reveal us that how commercial banks determined lending interest rate. Various standards are set by the country central bank on the loanable funds of the banks rates. Commercial banks individually determine lending rate on the basis of risk and cost related to the credit worthiness of borrower which significantly contributes to the nonperforming loans.

\subsection{Loanable Fund Theory}

Loanable fund theory is a modified version of classical theory of interest rate. The theory suggested that in process of investment and saving money play an important role, which brings variations in the income level. Therefore, change in the level of interest rate influence income and firm overall market value. So the banks and managers have to identify causes and factors which influence movement of interest rates over time (Munialo, 2014). Saunders and Cornett, (2008) ascertains that loanable fund theory of interest rate suggest that market interest rate is determined by the factors that affect the supply and demand for loanable funds for goods and services. So the rate of interest is the price where demand for loanable funds equals to the supply of loanable funds. Thus interest rate fluctuations rose due to change in the demand for loans or the loan supply available for the lending purpose. Sounders and Cornett, (2008) identified the two main factors that causes shit in the demand curves for loanable funds; these are monetary expansion and economic conditions. The economic condition includes unemployment rate, inflation rate and economic growth.

\subsection{Liquidity Preference Theory}

According to Saunders and Cornett (2008) that liquidity preference theory is grounded that long term maturities will hold by investor only if premium are offered for the compensation of future risk in the value of securities. They further stated that future interest rates, security prices and action of monitory policy are uncertain which makes the return of these investments risky. Keynes (2008) stated that in the situation of uncertainty, short term investment has greater marketability and has lower price risk as compared to long term investments. He further stated that interest rate is not the price which equalized the demand for an asset to invest with willingness to refrain from consumption. Therefore, the rate of interest is the price which fixes the desire to hold money at given rate of interest. So if the interest rate were high surplus money or cash will be available which no body wish to hold. Where if interest decreases the available amount of cash to hold exceed which no one willing to supply. Keynes (2008) that liquidity demand raises because of three motives; Transaction motives: individual will demand for money to meet their day to day transactions. People holds cash with them self in order to buy necessary items for their routine life. The cash amount that people keep with them self depends upon two factors, individual level of income and the period of time between pay (Keynes, 2008). Precautionary motives: people keep money with them self to fulfill uncertain situations. The quantity of money for precautionary purposes depends on the people 
income level, political and economic conditions in which they lives (Keynes, 2008). Speculative motives: people under speculative purpose keep money to receive benefit of change in the market price of securities in the future. If people perceived that the securities prices will be increases in the future speculator will buy them, in this circumstances the demand for holding cash decreases (Keynes, 2008).

\subsection{Definition of Nonperforming Loan}

The primary source of income of bank income is generated through loans and advances. Like, other businesses the purpose of any bank to maximized their shareholder wealth. Therefore, banks generate high income through lending and advancing than any other assets they lends to the customers. So the bank must be very careful about the safety and liquidity of such lending. So, the huge amount of NPLs puts bank in dangerous situation if the defaulted amount is more (Radha \&Vasudwan 1980). Hou (2001) stated that the definition of nonperforming loans is different from country to country there is no specific definition of nonperforming loans. Therefore, every country's banking system defined the nonperforming loans according to their rules and regulation of banking system. Different authors described nonperforming loans with different names. Such as, Basu (2003) describe the nonperforming loans as "bad loans". Where Fofack (2005) consider nonperforming loan as "impaired loans" where Berger and De Young (1997) describe "problems loans" interchangeably with nonperforming loans. Boudriga, Boulila and Jellouli (2009) described nonperforming loans as the amount borrowed by an individual which not generate income and not been repaid or the due date has been passed and payment is not made. Patersson and Wadman (2004), defined NPLs are those loans which do not generate income for the bank and its principal and interest are nor repaid within a specified time that are mentioned by the rules and laws of the country. A loan becomes nonperforming when loans borrowed from a bank and its interest and principal uncollected after 90 days of its maturity date (IMF, 2005). According to SBP (BSD, circular NO. 2 dated June 30, 2010) classified nonperforming loans in to three different categories. The details of these as follows

1.Substandard: those loans on which interest and principal or both are uncollected by 90 days from the date of its maturity this is classified as substandard loans. Banks are required to make $25 \%$ provision against outstanding amount of nonperforming loans.

2.Doubtful loans: those loans on which interest and principal or both are uncollected by more than 180 days from its maturity date so this will be consider doubtful. The bank will hold $50 \%$ provision on outstanding amount of nonperforming loans.

3. Loss: when interest and principal or both are uncollected for one year or more it will be consider loss loans. Banks are required to make $100 \%$ provision against the outstanding amount of nonperforming loans.

\subsection{Lending Rate}

Keynes,(2008)described lending rate is the rate which banks apply to meets the short term and medium financing needs of the private sector. This rate is usually varies to the objectives of financing and creditworthiness of the borrowers. The terms and conditions devoted to the lending rate varies by countries, which restricting their comparability. According to De Bock and Demyanets (2012) lending rate is the price of 
borrowed amount that a borrower pays to lender. According to Beck and Fuch (2004) lending rate are determine by the commercial banks for the disbursement of loans. If the economic condition is bade and high variation in the inflation and exchange rates banks charge high lending rates to compensate the default risk from risky borrowers, while banks reduce their lending rates the prosperous economic condition. Munailo (2014) stated that commercial banks business is exposed to the risk of default from borrowers. Therefore, lending rates enhance the poverty, financial crisis and political instability in the economy in the long run. According to Ngugi (2010) interest rate is the price of borrowed money which reflect market information anticipated future inflation. A recent study conducted by Cuncinelli (2015) examined the relationship between nonperforming loans and bank lending behavior in Italian banking sector. The sample for the study was 488 Italian banks for the period of 2007 to 2013. The result showed a significant negative relationship between nonperforming loans and lending behaviors of banks.

\subsection{Factors Affecting Banks Lending}

Bank lending sources are consists of deposits, reserves and capital. These sources are influences by various factors and can directly influence bank lending. Lending is considering the prime function of banks. Therefore, banks management should take precautionary measured to analyze the factors which badly affect bank lending (Semu, 2010). According to Read and Gill (1989), cited by Semu (2010) that the factors which affect the bank loans and having influence on nonperforming loans are: Capital position: Bank capital assists to protect funds of depositors. Banks capital and deposits has more effect on the extent of risk which banks take. Therefore, the banks that have more capital can assume high risk and provides long terms loans. Profitability: Several banks prefer more earnings than others. Banks that require high level earnings adopt the policy of aggressive lending, in which they prefer to provide consumer loans from which banks charge high interest rates and earn high profit. Deposit stability: Before lending of money the bank must ensure the stability of their deposits. When satisfactory provision for reserve is available, the bank then lends their money. Economic conditions: At the time of lending the bank must consider the economic conditions of the country as well as the factors that can adversely affect the local economic conditions. Furthermore, the fiscal and monitory policies of the country have an influence on banks' lending.

\subsection{Lending Rate and Nonperforming Loans}

De Bock and Demyanets (2012) describe that lending interest rate, is the interest amount which financial institutions charge when they lend money to the borrowers. These rates are set in accordance with the cost sustained by bank and the profit which the banks will earned on lending loans to its customers. Lending interest rate is the vital factor determined by banks when lending money to the various sectors of the economy. Default risk is the borrower's inability to repay his loans obligations on agreed terms. Due to expectation of defaults from borrowers commercial banks impose high interest rate on bad borrowers. So when lending interest rate increase the cost of lending amount also increase which leads extra burden of payment on customer installments. Therefore, the borrower income unchanged and lending rate increase, so the borrowers usually failed to repay their loans principal and interest on due time (Nkusu, 2011). The bank lending decision has more importance, because the future profitability and performance are 
determine by it. Banks are recently becoming very conscious in selection of customer to refrain the bad effect of nonperforming loans (Lata, 2015). According to Nkusu (2011), describe that low borrowers, has no collateral and property rights, to offer for taking loans from the banks on behalf of the collateral. Therefore, banks consider them as risky borrowers and charge high interest from them. These high intermediation cost leads low income borrowers to defaults and increase in the level of nonperforming loans. While Reddy and Mohan (2003), are viewed that lending policy and investment portfolio of banks determine the soundness of bank.More ever, the bank has to regularly identify loan quality with early alarming indicators to the regulatory authority of banks. Similarly, the financial and economic costs of the nonperforming loans has a significant negative affect on the private investment which reduce the banks credit to private sectors and enhance in their deposits liability (Fofack, 2009).Different studies have been conducted in the developed and underdeveloped countries. Different authors differently identify the causes and factors which have an influence on level of nonperforming loans. The followings are some researches that are been conducted on the factors that influence the level of nonperforming loans in different countries. But more attention has been given to the studies that have been conducted in the context of Pakistan. Farhan, Sattar, Chaudhry and Khalil (2012) investigated the economic factors causing nonperforming loans in Pakistani banking using primary data collected through questioner from the credit departments of 201 bankers by applying correlation and regression analysis to determine the impact of selected independent variables ( interest rate, energy crises, unemployment, inflation, GDP, and exchange rate) on the nonperforming loans. The study identified that the perception of banker in Pakistan is that interest rates, energy crisis, inflation and exchange rates have significant positive relation with nonperforming loans and growth in GDP rate has a significant negative relationship with nonperforming loans in Pakistan.

Badar and Yasmin, (2013) stated that banks profitability and liquidity are influenced by nonperforming loans which also affect the efficiency of banks as well as decrease their income. Therefore, more consideration should be given to banks nonperforming loans because it is adversely affect the survival of banks in the long run. Rajan and Chandra (2003) empirically examined the financial and economic factors influencing nonperforming loans in Indian commercial banks. The study applied regression model. They found a positive relationship between lending rate and nonperforming loans. Besides that loan to deposit ratio negatively impact nonperforming loans. Ahmad and Bashir (2013) examined the macro determinants of nonperforming loans in banking sector of Pakistan for the study period of $1990-2011$, for a sample of thirty banks. They utilized the time series data by applying OLS they used( annual GDP growth rate, lendingrate, unemployment rate, foreign money supply, stock price index, consumer price index, FDI and exchange rate) as a macroeconomic determinants of nonperforming. The study found significant negative association between interest rate and GDP growth on non-performing loans in banking sector of Pakistan. The study also justified the negative relationship between lending rate and nonperforming loans that when banks increase interest on lending and deposits. People with surplus money save their money with banks to earn high interest on their deposits, where investors are unwilling to borrow for their projects, while the opposite is true for the decreased in the 
interest rate. Jameel (2014), conducted a study on the bank significant factors of nonperforming loans in banking sectors of Pakistan, for a span of 2000 to 2010.The study collected time series data for(GDP growth rate, weighted average lending rate, credit deposit ratio, and capital adequacy ratio and loans maturity period) by applying multiple regressions. The study revealed that growth of GDP, loans maturity period, credit deposit ratio, and capital adequacy ratio have a significant negative relationship with nonperforming loans ratio. Where the nonperforming loans ratio has a significant positive relationship with weighted average lending rate in banking sector of Pakistan. Hassan et al. (2014) examined the social and bank specific factors influence the level of nonperforming loans in banking sector of Pakistan. The main objective of the study was to build and investigate the model that clarifies the relationship between nonperforming loans, banks specific factors and social factors in the context of Pakistan. The study used (lending interest rate, credit risk assessment, credit growth and credit monitoring) as bank specific variables. Whereas (political interference and bankers ineffectiveness) as bank social factors. The primary data for the study was collected from 150 employees of top 12 banks from Lahore city Pakistan through structure questioners. The study found that bank specific and social factors have a significant influence on the nonperforming loans, where interest rate has weak relationship with nonperforming loans in banking sector of Pakistan. Mehmood, Ahmad andAnjum (2012) examined the factors affecting loan repayment of agricultural credit in district Kasur, Punjab. The findings of the study showed that miss-utilization of loans, messy supervision of the banks officers, change of business and high interest rates are major causes on delay repayment on agricultural loans in district Kasur.

Mukhtar, Nartea and Gan (2012) examined loan repayment problem in micro finance institutions in Malaysia using logistic regression model they found that borrower characteristics and mode of repayment are the main factors which affect loan repayment of borrowers in Malaysia. Awan et al. (2015) investigated the causes of loan defaults and its impact on the profitability of the Pakistani banking sector. They found that the main causes of loan defaults are deficiency of business management knowledge, ineffective monitoring, late loan approvals, bad weather conditions and opposition of borrowers to repay their loans. They also found that farmers and traders are normally defaulted. Benard (2011) examined the effect of interest rates on loan repayment in Uganda equity bank a case study of Masindi branch. Person correlation is applied and found that that there is a negative correlation between interest rates and nonperforming loans. Ongwezo (2005) carried out a research on commercial banks of Kenya, for a sample of 38 banks in between 2000 to 2004 to determine the relationship between nonperforming loans and interest rate. Regression analysis was applied the study found an insignificant positive relationship between nonperforming loans and interest rates in banking sector of Kenya. A study by Tireito (2012), on the relationship between interest rate and nonperforming loans in commercial banks of Kenya in between 2007 to 2011, the study found that interest rate has not significantly correlated with nonperforming loans.

\subsection{Empirical Studies on Determinants of NPLs}

Different studies have been conducted on the determinants of nonperforming loans. Their result identified that nonperforming loans are determined by external and 
internal factors. Therefore, the followings are the empirical studies that have been conducted on the determinants of nonperforming loans.

\subsubsection{Single Country Studies on Determinants of Nonperforming Loans}

The study conducted by Keeton and Morris (1987) in American banking sector for a period of 1997 to 1985 to determine the factors contributes to impaired loans. The study found out that poor performance of agriculture and energy sector and bad economic environment are the causes that influence the impaired loans in American commercial banks. Saba, Kouser and Azeem(2012) examined the determinants of nonperforming loans in U.S banking sector from 1998 to 2010 using correlation and regression analysis. The study found that real GDP per capita and total loans are positively associated with nonperforming loans, while interest rates are negatively associated with nonperforming loans. According to Janvislo and Muhammad (2013) investigate the commercial banks of Malaysia for the period of 1997 and 2012 using dynamic panel data model the study revealed that the lending interest rate and GDP have a positive effect on nonperforming loans ratio in commercial banks of Malaysia. According to Ha, Trien, and Diep (2014) the study in Vietnams to investigate the macro determinants of nonperforming loans and stress testing in commercial banks covering the period between 2008-2013 found out that the GDP rate is not significantly associated with nonperforming loans while the lending rate is positively associated with non-performing loans.

The study also found that the inflation and exchange rates has no influence on nonperforming loans in commercial banking sector of Vietnams. Mehmood, Younas and Ahmad (2013) empirically examined bank individual and macroeconomics determinants of nonperforming loans in commercial banks of Pakistan applying fixed effect model for a sample of 13 banks for a period of 2013-2012. The study found that banks individuals and macroeconomic factors have an influence of on nonperforming loans in banking sector of Pakistan. Kurti (2016), examined the relationship between macroeconomic variables ( GDP, inflation rate, lending interest rate, exchange rate and unemployment ) and nonperforming loans in Albania banking sector for a period of 2000 to 2013 using regression model the result revealed that GDP growth, inflation and lending rates have a significant negative relationship with nonperforming loans ratio, while foreign exchange rates, and unemployment has a significant positive relationship with nonperforming loans ratio for the study period in Albanian banking sector. Cucinelli (2015) conducted a study in between 2003-2007 in Italian banking sector to examine the relationship between nonperforming loans and lending behavior of banks. The study found a significant negative relationship between unemployment, nonperforming loans and bank lending behavior. While GDP growth rate and deposit rate negatively related with bank lending behavior.

A study by Tomak (2013) on factors effecting lending behavior in commercial banks of Turkey, the sample was consist of 18 banks and the data was collected from 2003 to 2012. The study found bank size, long term loan access and inflation has positive relationship with bank lending behavior, Where GDP and interest are found insignificant to bank lending behavior. A study by Tireito (2012) on the relationship between interest rate and nonperforming loans in commercial banks of Kenya in between 2007 to 2011, the study found that interest rate has not significantly correlated with nonperforming 
loans. According to Daniel and Wandera (2013) the study on impact of credit information sharing on NPLs in Kenya commercial banking sector. The data collected for the span of 2007-2012, and the data was both primary and secondary in nature. The study consists of lending interest rate, asymmetry information, credit criteria, management of loans, and legal framework. The study showed a positive effect of lending rate on NPLS. Ongwezo (2005) examined the relationship between market interest rate and nonperforming loans in commercial banks of Kenya for a period of 2000-2005. The research concludes that there was a positive relationship between interest rate and nonperforming loans. But the test shows a weak relationship between the variables.

Kalirai and Scheicher (2002) conducted research in Australia in between 1990 to 2001. The study found that lending interest rate, stock market performance and business cycle are the main causes which influence the quality of loans in Australia. Befondi and Ropele (2011), conducted research on determinants of nonperforming loans in Italian banking sector for a period of 1990-2010.they found that lending rates and unemployment are positively associated with nonperforming loans, While growth in GDP is negatively associated with nonperforming loans. Swamy (2012), ascertain the macroeconomic economic and industry specific determinants of nonperforming loans in commercial banks of India. The study applied the technique of panel data for the span of 1997 to 2009. The study used econometric module. The result shows that lending rate has insignificant relationship with nonperforming loans. Where bank size has significant negative relationship with nonperforming loans in banking sector of India for the study period they conclude that foreign and private banks are more efficient in term of credit management which leads to lower nonperforming loans.

\subsection{Hypothesis}

\section{$\boldsymbol{H}_{1}$ : There is a significant relationship between lending rate and nonperforming loans in commercial banks of Pakistan.}

\section{Research Methodology}

\subsection{Research Design}

Research design is plan or layout used to generate answers to the research questions. The present research is quantitative in nature. And will use secondary data. The data will be obtained from state bank of Pakistan (SBP) and from the selected commercial banks annual reports and from books, and various journals.

\subsection{Sample Size}

The current study will examine the relationship between lending rate and nonperforming loans in commercial banks of Pakistan. For this purpose, sample for the study was consists of top five commercial banks. These banks are selected on the basis of their total asset. The study collect the data from the period of 2008 to 2014 i.e. 7 years data.

\subsection{Data Analysis Techniques}

Various statistical methods and tools are used to test the relationship among the variables. The present study will apply descriptive statistics, multiple regression and correlation analysis to examine the relationship between lending rate and NPLs in commercial banks of Pakistan. The data will be analyzed through SPSS 21.0 version. 


\subsection{Research Model}

The study will use Lending rate, as independent variables and nonperforming loans (NPLs) loans as a dependent variable

The regression model is as shown below.

$$
\mathrm{Y}=\alpha+\beta_{1} \mathrm{X}_{1}+\beta_{2} \mathrm{X}_{2}+\varepsilon
$$

Where;

$\mathrm{Y}=$ nonperforming loans measures as a ratio of total nonperforming loans togross loans and advances.

$\mathrm{X}_{1}=$ commercial bank lending rate proxy by year end KIBOR rate

$\mathrm{X}_{2=}$ bank size proxy by $\log$ of total assets

$\alpha=$ intercept

$\beta_{1 \text { and }} \beta_{2}=$ are regression coefficient

$\varepsilon=$ error term

\section{Data Analysis, Results and Discussions}

The objective of the study was to determine the relationship between lending rate and nonperforming loans in commercial banks of Pakistan. This section presents the findings and analysis with regard to the objective of the study. The findings of the study are presented in regression and correlation. Data was collected from top five Pakistani commercial banks from 2008-2014. The sources of data include annual reports of selected commercial banks and state bank of Pakistan statistical bulletins. Based on the variables of the study data was collected on nonperforming loans, total assets and lending rate.

Table 4.1 Descriptive Statistics

\begin{tabular}{|llllll|}
\hline & $\mathrm{N}$ & Minimum & Maximum & Mean & $\begin{array}{l}\text { Std. } \\
\text { Deviation }\end{array}$ \\
\hline NPL & 35 & 6.20 & 16.60 & 10.4086 & 3.03445 \\
Size & 35 & 12.81 & 14.44 & 13.6339 & .41567 \\
LR & 35 & 9.75 & 16.11 & 12.2300 & 2.23716 \\
Valid N (listwise) & 35 & & & & \\
\hline
\end{tabular}

The above table indicates that NPL has a minimum valve of 6.20 and having maximum value of 16.60. It has a standard deviation of 3.03445 and having an average value of 10.4086, which shows that an average amount that bank lent became nonperforming. The lending rate has a lowest value of 9.75 and highest value is 16.11. It has a standard deviation of 2.23716 and having mean value of 12.2300. Size has a lowest standard deviation of .41567 and highest mean of 13.6339 which indicates that the data in this group is highly spread out over a wide range of data. 
Table 4.2: Correlation Analysis

\begin{tabular}{|llll|}
\hline & NPL & Size & LR \\
\hline NPL & 1 & 0.648 & -0.197 \\
Size & 0.648 & 1 & -0.591 \\
LR & -0.197 & -0.591 & 1 \\
\hline
\end{tabular}

From the above table the relationship between lending rate and nonperforming loan is negative -.197 . This means that weak inverse relationship between lending rate and nonperforming loans exist. It depicts that as lending rate increase nonperforming loans decrease. While the relationship between banks size and nonperforming loans is .648. It shows that a significant positive relationship exist between bank size and nonperforming loans.

Table 4.3 Model Summary

\begin{tabular}{|lllll|}
\hline Model & $\mathrm{R}$ & $\mathrm{R}$ Square & $\begin{array}{l}\text { Adjusted } \\
\text { Square }\end{array}$ & $\mathrm{R}$ \\
\hline 1 & $\begin{array}{l}\text { Std. Error of } \\
\text { the Estimate }\end{array}$ \\
\hline a. & Predictors: (Constant), LR, Size & 0.44 & 2.27069 \\
\hline
\end{tabular}


Coefficient of determination describe the degree to which variation in one variable (dependent variable) are explained by the variation in one or more explanatory variables. From the table 4.3 of model summary the result shows that the value of R-square is .473 this shows that the two independent variables (LR,Size) that used in this study explained 47.3 percent variation in the dependent variable which therefore, indicates that the factors which influence nonperforming loans(NPL) was not study in this research is 53.7 percent. However, further study can be conducted to examine the other factors which influence the level of nonperforming loans in commercial banks of Pakistan.

\section{Table 4.4 ANOVA}

\begin{tabular}{ccccccc}
\hline \multirow{2}{*}{ Model } & $\begin{array}{c}\text { Sum of } \\
\text { Squares }\end{array}$ & Df & $\begin{array}{c}\text { Mean } \\
\text { Square }\end{array}$ & F & Sig. \\
\hline \multirow{2}{*}{1} & Regression & 148.074 & 2 & 74.037 & 14.359 & $.000^{\mathrm{b}}$ \\
& Residual & 164.993 & 32 & 5.156 & & \\
& Total & 313.067 & 34 & & & \\
\hline
\end{tabular}

. Dependent Variable: NPL

.Predictors: (Constant), LR, Size

Analysis of variance provides calculations about the variation in the regression model on the basis of significance test. From the above table it is found that the significance value is .000 which shows that the model is statistically significant to predict the effect of lending rate (LR) and bank size on nonperforming loans in commercial banks of Pakistan.

Table 4.5 Multiple Regression

\begin{tabular}{|cccccc|}
\hline Model & $\begin{array}{c}\text { Unstandardized } \\
\text { Coefficients }\end{array}$ & $\begin{array}{c}\text { Standardized } \\
\text { Coefficients }\end{array}$ & t & Sig. \\
& B $\quad$\begin{tabular}{ccccc|} 
Std. \\
Error
\end{tabular} & Beta & & \\
\hline (Constant) & -75.655 & 17.533 & & -4.315 & 0 \\
Size & 5.964 & 1.162 & 0.817 & 5.134 & 0 \\
LR & 0.388 & 0.216 & 0.286 & 1.797 & 0.082 \\
\hline
\end{tabular}

The above table 4.5 shows the results of multiple regression analysis for dependent and independent variable. From the finding the regression equation can be as:

$\mathrm{Y}=\alpha+\beta_{1} \mathrm{X}_{1}+\beta 2 \mathrm{X} 2+\varepsilon$

$Y=-75.665+5.964$ size $+.388 \mathrm{LR}$ 
Which shows the intercept $\alpha$ value is -75.655 it shows that if the value of all predictor are taken constant at zero the nonperforming loans value will be -75.655 . Where $\beta_{1}$ value is 5.964 which show that if size (TA) change by one unit nonperforming loans will be change by 5.964 units if all other variables are held constant. Therefore, the study found significant positive relationship between bank size and nonperforming loans. The relationship is significant at $1 \%$ significance level because the p-value is less than 0.01 . The $\beta 2$ value is .338 which shows that if lending rate increase by one unit and other predictor remain constant nonperforming loans will be increases by .338 . So the study found positive relationship between lending rate and nonperforming loans. This relationship is significant at $10 \%$ level of significance because the p-value is $<.10$ on the basis of this $\mathrm{H}_{1}$ is accepted. Therefore, high lending interest rate increases the level of nonperforming loans. After obtaining the result, various literatures have given different results about the relationship between lending rate and nonperforming loans. Some studies found weak or negative relationship between lending rate and nonperforming loans (Ahmad \& Bashir, 2012; Hassan et al. 2014; Swamy, 2012). They are of the view that if lending rates increase nonperforming loans tends to decrease. Some studies have found a significant positive relationship between lending rate and nonperforming loans (Jameel, 2014; Janvislo \& Muhammad, 2013; Ha et al. 2014). Therefore, the finding of present study is consistent with those studies that support a significant positive relationship between lending rate and nonperforming loans.

\section{Conclusion and Recommendations \\ 5.1 Conclusion}

The main purpose of the study was to examine the relationship between lending rate and nonperforming loans in commercial banks of Pakistan. The study collects data on bank size and nonperforming loans from the annual reports of commercial banks and lending rates data was collected from the state bank of Pakistan statistical bulletins for the period of 2008-2014 and the data was analyzed through SPSS to examine is there any relationship between lending rate and nonperforming loans. The study used correlation and regression methods. The study found a significant positive relationship between lending rate and nonperforming loans in commercial banks of Pakistan. This implies that if lending rate change nonperforming loans also change. Furthermore, the studied independent variables in this study has only 47.3 percent effect on nonperforming loans while the other factors which contribute to level of nonperforming loans are not covered in this study counted for 53.7 percent. So future studies can be conducted to determine the other factors which are responsible for nonperforming loans in banking sectors of Pakistan.

\section{References}

Ahmad, F., \& Bashir, T. (2013). Explanatory power of bank specific variables as determinants of non-performing loans: Evidence from Pakistan banking sector. World Applied Sciences Journal, 22(9), 1220-1231.

Arby, M. F. (2003). Structure and Performance of Commercial Banks in Pakistan.State Bank of Pakistan.

Asantey, J. O., \& Tengey, S. (2014). An Empirical Study on the Effect of Bad Loans on Banks' Lending Potential and Financial Performance: The Case of SMEs -- 
Lending In Ghana. Impact: International Journal of Research in Business Management (IMPACT: IJRBM), 2(11), 1-12.

Awan, A.G., Nadeem, N., \& Malghani, F.S. (2015). Causes of Loan Defaults In Pakistani Banks: A Case Study Of District D.G. Khan. Scient (Lahore), 27(3), 2579-2587.

Badar, M., \& Javid, A. Y. (2013). Impact of macroeconomic forces on nonperforming loans: An empirical study of commercial banks in Pakistan. WSEAS Transactions on Business and Economics, 10 (1), 40-48.

Beck, T. \& Fuchs, J. (2004). Structural issues in the Kenyan financial system: Improving Competition and Access. World Bank Policy Research Working Paper.

Berger, A. N., \& DeYoung, R. (1997). Problem loans and cost efficiency in commercial banks. Journal of Banking \& Finance, 21(6), 849-870.

Bofondi, M., \& Ropele, T. (2011). Macroeconomic determinants of bad loans: evidence from Italian banks. Bank of Italy Occasional Paper, (89).

Boudriga, A., Boulila, T. N., \& Jellouli, S. (2009). Banking supervision and nonperforming loans: a cross-country analysis. Journal of financial economic policy, 1(4), 286-318.

Cucinelli, D. (2015). The Impact of Non-performing Loans on Bank Lending Behavior: Evidence from the Italian Banking Sector.Eurasian Journal ofBusiness and Economics 2015, 8(16), 59-71.

De Bock, R., \& Demyanets, M. A. (2012). Bank asset quality in emerging markets: Determinants and spillovers (No. 12-71).International Monetary Fund.

Espinoza, R. A., \& Prasad, A. (2010). Nonperforming loans in the GCC banking system and their macroeconomic effects. IMF Working Papers, 1-24.

Farhan, M., Sattar, A., Chaudhry, A. H., \& Khalil, F. (2012). Economic Determinants of Non-Performing Loans: Perception of Pakistani Bankers. European journal of business and Management, 4(19), 87-99.

Fofack, H. (2005). Nonperforming loans in Sub-Saharan Africa: causal analysis and macroeconomic implications. World Bank Policy Research Working Paper, (3769).

Fofack, H. (2009). Causality between external debt and capital flight in Sub-Saharan Africa. World Bank Policy Research Working Paper Series.

Ha, V. T. N., \& Le VinhTrien, H. D. (2014). Macro Determinants on Non-performing Loans and Stress Testing of Vietnamese Commercial Banks'; Credit Risk.

Hassan, H. U., Ilyas, M., \& Rehman, C. A. (2015). Quantitative Study of Bank-Specific and Social Factors of Non-Performing Loans of Pakistani Banking Sector. International Letters of Social and Humanistic Sciences (ILSHS), 2, 192-213.

Hou, Y. (2001). The Non-performing Loans: Some Bank-level Evidences', Journal of Banking and finance, pp.25-46, viewed December 2012.

Jameel, K. (2014). Crucial Factors of Nonperforming loans Evidence from Pakistani Banking Sector. International Journal of Scientific \& Engineering Research, 5(7).

Joseph, M. T., Edson, G., Manuere, F., Clifford, M., Michael, K., \& Joseph, M. T. (2012). Interdisciplinary Journal of ContemporaryResearch in Business.

Justin, F. (2013). What we've learned from the financial crisis. New York: Harvard Business Review. 
Kalirai, H., \& Scheicher, M. (2002). Macroeconomic stress testing: preliminary evidence for Austria. Financial Stability Report, (3), 58-74.

Keeton, W. R. \& Morris, C.S. (1987). Why Do Banks' Loan Losses Differ, Economic Review, Federal Reserve Bank of Kansas City, pp. 3-21.

Keynes, J. M. (2008). General theory of employment, interest and money. New Dhlhi,ND: Atlantic Publishers \& Dist.

Kidwell, D., Blackwell, W., Whidbee, D. A., Richard, C., \& Pereso, R. C. (2008). Financial institutions, Market and Money. New York, NY: John Wiley \& Sons.

Kwambai, K. D., \& Wandera, M. (2013). Effects of Credit Information Sharing on Nonperforming Loans: The Case of Kenya Commercial Bank Kenya. European Scientific Journal, 9(13).

Lata, R. S. Non-Performing Loan and Profitability: The Case of State Owned Commercial Banks in Bangladesh.World Review of Business Research, Vol. 5(3). Pp. $171-182$.

Makri, V., Tsagkanos, A., \& Bellas, A. (2014). Determinants of non-performing loans: The case of Eurozone. Panoeconomicus, 61(2), 193.

Masood,O. \& Aktan, B. (2009). Determinants of Non- performing loans :comparative analysis"e АКТУАЛЬНІ ПРОБЛЕМИ ЕКОНОМІКИ, Vol.102(12), PР.251-163.

Mehmood, Y., Ahmad, M., \& Anjum, M. B. (2012). Factors Affecting Delay In repayments of agricultural credit: a case study of district Kasur Punjab Province. world applied science, journal, 17(4), 447-451.

Mukhtar, S.H., Nartea, G., \& Gan, C. (2012). Determinants of micro credit loans repayment problem among micro finance borrowers in Malaysia. International Journal of Business And Social Research (IJBSR), Vol.2(7).

Munialo, A. J. L. (2014). The relationship between lending rate and non performing loans in commercial banks in Kenya (MBA research project, School of Business, University of Nairobi).

Ngugi, R. (2001). An empirical analysis of interest rate spread in Kenya (Vol. 106). Nairobi: African Economic Research Consortium.

Nkusu, M. (2011). Nonperforming loans and macro financial vulnerabilities in advanced economies. IMF Working Papers, 1-27.

Petersson, J. \& Wadman, I. (2004). Non Performing Loans-the markets of Italy and Sweden.

Radha, M., \& Vasudevan, S. V. (1980). A Text Book of Banking: Law, Practice and Theory of banking.

Rajan, R., \& Dhal, S. C. (2003). Non-performing loans and terms of credit of public sector banks in India: An empirical assessment. Occasional Papers, 24(3), 81121.

Read, E.W. \& Gill, E.K. (1989). Commercial banking, Fourth edition, New Jersey: Englewood cliffs.

Richard, E. (2011). Factors that cause non-performing loans in commercial banks in Tanzania and strategies to resolve them. Journal of management policy and practice, 12(7), 50.

Rizvi, W., \& Khan, M. M. S. (2015). The Impact Of Inflation On Loan Default: A Study 
On Pakistan. Australian Journal of Business and Economic Studies, 1(1).

Saba, I., Kouser, R., \& Azeem, M. (2012). Determinants of Non-Performing Loans: Case of US Banking Sector. The Romanian Economic Journal, Year XV, 44.

Salas, V., \& Saurina, J. (2002). Credit risk in two institutional regimes: Spanish commercial and savings banks. Journal of Financial Services Research, 22(3), 203-224.

Saunders, A., \& Cornett, M. (2008). Financial Institutions Management: A Risk Management Approach with S\&P card. Irwing-McGraw Hill, 6th.

Semu, Z. S. (2010). Impact of reducing loan by Ethiopian banks on their own performance (MBA research project, University of South Africa).

Škarica, B. (2014). Determinants of non-performing loans in Central and Eastern European countries. Financial theory and practice, 38(1), 37-59.

Swamy, V. (2012). Impact of macroeconomic and endogenous factors on non performing bank assets.Available at SSRN 2060753.

Tireito, J. K. (2009). The Relationship Between Interest Rates And Non Per-Forming Loans In Commercial Banks In Kenya (MBA research project, School of Business, University of Nairobi).

Tomak, S. (2013). Determinants of Commercial Banks' Lending Behavior: Evidence From Turkey. Asian Journal of Empirical Research, 3(8), 933-943.

Walsh, C. E. (2010). Monetary theory and policy.MIT press.

Waweru, N., \& Kalani, V. M. (2009). Commercial banking crises in Kenya: Causes and remedies. African Journal of Accounting, Economics, Finance and Banking Research, 4(4).

Zelalem, T. (2013). Determinants of Non-performing Loans: Empirical Study on Ethiopian Commercial Banks (MBA reseach project, AAU). 